\title{
TOURISM ENTREPRENEURSHIP IN THE DANUBE SHORE (CLISURA DUNĂRII) - POTENTIAL AND PROSPECTS
}

\author{
Adrian-Costinel Tănase ${ }^{1}$ \\ Florența-Diana Tănase ${ }^{2}$ \\ Suzana Demyen ${ }^{3}$
}

DOI: https://doi.org/10.31410/tmt.2020.253

\begin{abstract}
Tourism is a global industry that brings considerable revenue to all states that know how to manage it. This chapter highlights aspects related to entrepreneurship in tourism along the Danube Shore (Clisura Dunării), a touristic area of extreme natural beauty, along with anthropogenic sights, a zone that can become a development engine for the region, by capitalizing on local resources and engaging related industries.

The first part of the work presents the current state of knowledge in the field of entrepreneurship and, in particular, of entrepreneurship in tourism, in order to later describe the Danube Shore and the most representative touristic sites for this area. The chapter also presents aspects related to the analysis of the correlations between the GDP of Carass-Severin County and the number of overnight stays, as well as the results of a study on the touristic potential of the Danube Shore, a study conducted through a survey based on a questionnaire.
\end{abstract}

Keywords: Business, Economic growth, Local development.

\section{INTRODUCTION}

9 9 Tourism, due to its distinct field of activity by its content and role, is considered a component of the high importance of economic and social life for many countries" (Gherghina, 2017).

The huge tourism industry brings considerable revenues worldwide, and in the European Union countries such as France, Italy, Spain, Croatia, and Malta stand out. In the European Union - 28, the number of overnight stays is impressive. In 2015, there were 2.94 billion overnight stays in tourists' accommodation units, 1.5 billion of them by residents, and 1.4 billion by non-residents (Eurostat, 2018). As for the top of the regions with the most overnight stays according to NUTS 2, in 2016, on the first three places ranked the Canary Islands, Catalonia, the Adriatic Coast, with 103 million, 80 million, respectively 70 million overnight stays.

Practicing an appropriate kind of tourism brings advantages such as:

- job creation,

- increase the income of the inhabitants of the target area,

- the possibility of recognizing products as local brands or as products with a protected geographical indication.

University Babeș - Bolyai of Cluj - Napoca, Mihail Kogălniceanu Street, no.1, Romania

University Babeș - Bolyai of Cluj - Napoca, Mihail Kogălniceanu Street, no.1, Romania

University Babeș - Bolyai of Cluj - Napoca, Mihail Kogălniceanu Street, no.1, Romania 
"Tourism can be a force for good in our world, playing a part in protecting our planet and its biodiversity, and celebrating what makes us human: from discovering new places and cultures to connecting with new people and experiences" (Guterres, 2020).

As regards the situation in Romania, tourism is a particular area that can be exploited. Romania is known internationally especially for the beauty of the Danube Delta or the myth of Dracula, the fortress of Sighisoara, the cities of Brasov and Sibiu, but these are just some of the tourist sites in our spectacular country. When it comes to the Western region of Romania, the area that stands out is the Danube Shore or the Danube Gorge (Clisura Dunării), an increasingly sought-after touristic area, under constant development.

As for the number of overnight stays in this region, we see a significant increase from 1.8 million in 2014 to about 2.5 million overnight stays in 2019. Also, according to Eurostat, in 2017, the number of nights spent in tourist accommodation was 1277.45 (per 1000 inhabitants) compared to 2285.79 overnight stays in the South East Region, where the Danube Delta or the Central Region stands out with 2500.42 overnight stays, the leading region of Romania in terms of tourism.

When analysing the activities in the field of tourism, we must implicitly take into account the GDP macroeconomic indicator, because the connection between the two is well known, an aspect highlighted in the following section of the chapter.

We remark an upward trend in the number of overnight stays in the Western Region, and in terms of GDP, the situation is similar. Thus, in 2000 the GDP registered a value of 7577.6 million lei (1.88 lei $=1$ euro), and in 2017 it reached a value of 80895.3 million lei (4.77 lei $=1$ euro). Tourism also employs a substantial workforce. In Romania, we see an increase in the number of people employed in tourism activities, hotels, or restaurants from 163,311 persons in 2014 to 195,956 employees in 2018.

Undoubtedly, tourism is a vector of development for a region because it involves both local resources and resources from other areas, and the planning of a touristic destination development must take into account the socio-economic principles along with those connected to environmental protection (Štetić \& Trišić, 2019).

\section{ANALYSIS OF THE CURRENT STATE OF RESEARCH ON ENTREPRENEURSHIP IN TOURISM}

\subsection{The importance of entrepreneurship development for the business environment}

The sustainability of the business environment is closely linked to entrepreneurship, which is considered one of the "main pillars of economic development” (Mahmoud et al, 2019, p. 107, Biswas, Mamun-Or-Rashid, 2018), irrespective of the concerned area. Other researchers (Forouzandeh et al, 2015) identify a positive correlation between economic growth and entrepreneurship on a national level, but also considering the level of education of the population. However, Kuratko (2009) (in Gică et al, 2014) lists several factors that contribute to this effect, including leadership style, management, development capacity, innovation, productivity, etc.

Classical approaches, in theory, link the notion of entrepreneurship to the behaviour of individuals, delimiting direct relationships with risk attitude, motivation, and ability to innovate, also 
emphasizing the importance of personal skills and characteristics. The definitions are given to this term and the ideas related to it are numerous, a synthesis is presented below:

Table 1. Approaches to the concept of entrepreneurship

\begin{tabular}{|l|l|l|}
\hline Cantillon & $1680-1734$ & $\begin{array}{l}\text { "A domain that generates profit, but can always receive newcomers who pur- } \\
\text { sue the potential profit that can be generated". }\end{array}$ \\
\hline Say & 1803 & $\begin{array}{l}\text { "Places the entrepreneur at the core of all economic activities, both produc- } \\
\text { tion and distribution of goods and services for consumption, overlapping the } \\
\text { functions of the entrepreneur with those of the manager". }\end{array}$ \\
\hline Dollinger & 1995 & $\begin{array}{l}\text { "Creation of an innovative economic organization in order to make a profit, } \\
\text { in conditions of risk and uncertainty". }\end{array}$ \\
\hline Schumpeter & 1934 & $\begin{array}{l}\text { "Emphasizes innovation and the combination of resources, writing that the } \\
\text { entrepreneur must be strong enough to swim against the current of the soci- } \\
\text { ety in which he or she lives". }\end{array}$ \\
\hline Drucker & 1985 & $\begin{array}{l}\text { "Entrepreneurship is the creation of an organization, regardless of the orga- } \\
\text { nization's ability to support itself". }\end{array}$ \\
\hline Timmons & 1989 & $\begin{array}{l}\text { „Entrepreneurship is the ability to do something out of nothing. It is the ini- } \\
\text { tiation and construction of an enterprise, rather than the gaze and admiration } \\
\text { of one". }\end{array}$ \\
\hline
\end{tabular}

Source: elaborated by the authors, based on the information found in the bibliographic references

The literature has taken a strong upsurge from this viewpoint, establishing clear relationships between entrepreneurship, local and even regional development. Joseph Schumpeter, in an attempt to define entrepreneurship, emphasized the importance of innovation but also creativity (Sheikh, 2015), drawing attention to the significance of the novelty, both in terms of production methods and the market, product, or organization. He outlined three development directions in this regard, namely: local entrepreneurship, innovation, and investment financing, to which the Aspen Institute Romania studies add a fourth element: public support on the local level, in order to encourage entrepreneurial initiatives. However, his research links the idea of entrepreneurship to those of "change, turbulence and instability" (Jaafar et al, 2011), while inducing the idea of the need for capitalizing on market opportunities.

Consequently, over these past three decades the importance of entrepreneurial initiatives, both in terms of small and large-scale business, has greatly increased in terms of industrial parks and clusters (Maticiuc \& Petrache, 2016).

It is also important to remind the significance of entrepreneurship as a "major source of employment" (Ciochină et al, 2016, p. 264, Sima et al, 2015). We cannot ignore the need to adapt to the conditions of the economic environment, nor the social impact, but the success of entrepreneurial activities is conditioned by a wide variety of factors. In this respect, a mandatory condition becomes the compatibility between the business idea and the conditions offered by the market, the efficient management of the available resources, and the maximum exploitation of the existing potential. The main challenges that arise when implementing a business idea are also to be taken into account, namely (Nongsiej \& Shimray, 2017): clarifying the idea and business concept adopted, ensuring the necessary financial resources, attracting the right people to the team, focusing on the appropriate customer segment, objectively evaluating potential.

The development of the business environment is often slowed down by factors with a negative effect on long-term activity, which often induces insecurity, uncertainty and does not allow objective long-term planning, often lacking a coherent business expansion strategy, especially 
on the SMEs level. The high problems of bureaucracy, the scarce knowledge in the field, the absence of certain categories of skills in the professional sphere, the lack of interest or financial resources are considered as representative challenges that today's entrepreneurs currently face (Zimmerman \& Chu, 2013).

\subsection{Entrepreneurship in tourism - overview}

Tourism and the hospitality industry, in general, are perceived as exponents of a sector with rapid growth potential (Mahmoud et al, 2019, p. 110; Sheikh, 2015), especially in developing countries (according to reports prepared by the European Commission). The OECD reports (2020) consider domestic tourism to be the very backbone of this sector, generating $4.4 \%$ of GDP, representing $6.9 \%$ of jobs and $21.5 \%$ of service exports.

In the literature, the direct link between the representative indicators of this sector and the level of economic growth of a country was established by authors such as Çağlayan, Şak, and Karymshakov (2012) who consider the Gross Domestic Product as a relevant analysis indicator for establishing this correlation. The authors propose the study of causal links through the prism of a panel approach, using the Granger analysis in three stages, similar conclusions being pointed out by Dees (2002) and Li (2008).

Tourism is currently undergoing a period of growth in terms of the development of this field, being considered even "the third economic phenomenon in the world, after the oil and automotive industry" (Forouzandeh et al, 2015), even exhibiting an advantage over them grace to its ,green" nature. Also, tourism is no longer considered a symbol of status but has become a necessity over time (Sikari, 2018).

The positive influence of this sector on the overall economic development of a country was also studied from the perspective of the need to identify a causal relationship between the factors involved, one of them being the development potential of entrepreneurship in the field. "The tourism sector is heavily dependent on entrepreneurship and cannot survive in the long run if it is not both sustainable and entrepreneurial" (Butkouskaya et al, 2020), as we are also witnessing a "need for recognizing the importance of entrepreneurship in tourism" (Pădurean et al, 2015), especially on the regional level. In that context, it can contribute both to the achievement of a brand strategy (Oliveira, 2014) and the reduction of the poverty level, through the direct effect generated by the "salaries and earnings of those who work in this field" (Ashley et al, 2007). The literature also mentions in this case the importance of classical production factors: labour, nature, and capital, but Sullivan (2003) proposes a supplement, namely information or knowledge (Panasiuk, in Bednarczyk \& Gancarczyk, 2013).

Entrepreneurship in tourism has benefited from a long period of attention, the proof of success in this regard being the large hotel chains (Brookes \& Altinay, 2015), recognized worldwide. However, success in the field does not come out of anywhere, it is closely connected to the level of customer satisfaction, the overall development of the community, the financial possibilities of consumers of these services, etc. (Bardolet \& Sheldon, 2008). Some sources also focus on creativity, however, from the perspective of teamwork (Bascavusoglu-Moreau et al, in Bednarczyk \& Gancarczyk, 2013), and on the importance of encouraging innovation by local authorities (Najda-Janpszka, in Bednarczyk \& Gancarczyk, 2013). 
From the perspective of firms' size, however, small and medium enterprises in any field remain the engine of the economy (Manciu, 2019), being more adaptable and ,providing a much faster response to society's needs" (Ciochină et al, 2016), and tourism also follows this trend, all the more so as it simultaneously stimulates the development of the trade and services fields. Also, the evolution trends in tourism indicate a predilection for rural tourism, oriented to nature and organized in the form of small businesses (Lordkipanidze et al, 2005). On the other hand, Štetić and Trišić emphasize the role and importance of ecosystems in the creation of tourism activities (Štetić \& Trišić, 2018).

Although we can identify in practice many examples of large enterprises in the tourism sector, SMEs remain representative for these activities, Morisson (1996, in Jaafar et al, 2011) justifying this orientation towards small businesses by the following arguments:

- the small size of a business allows for much faster feedback and adaptation to customer needs;

- many of these businesses are family businesses, being managed and even passed down from one generation to another;

- they have a higher level of adaptation to specific market segments;

- they do not require significant equity.

Various sources explain the role of entrepreneurship in tourism, as well as how it can contribute to the economic development process. However, there is the issue of choosing the most appropriate development strategies, depending on the specifics of the area, and thus adapting the activity taking into account the profile of potential customers and promoting a „responsible entrepreneurship" (Lordkipanidze et al, 2005), even sustainable tourism, in the sense that "entrepreneurs in this field must not jeopardize the future of next generations" (Akrivos, 2014). The reports prepared by the World Tourism Organization indicate as main reasons why individuals choose to go to various destinations: relaxation, recreation, business trips, visiting acquaintances, family, and friends, etc., a fact confirmed also by the authors in the field, who consider that tourist services are ,created to satisfy the needs of a superior order”, such as ,information, organisation, transport, accommodation, alimentation, relaxation and treatment" (Gherghina, 2018).

Furthermore, Carvalho and Sardinha indicate the advantages generated by entrepreneurial activities in the field of tourism, by reference to local communities: the creation of new jobs and thus the integration of disadvantaged categories of people into employment, increasing the number of economic agents in this field, enhancing the living standards of the population, improving the quality of infrastructure, more active promotion and the creation of local brands.

Biswas and Mamun-Or-Rashid (2018) explain the connection between the notions of "tourism development" and "economic development" in terms of the effects generated by capitalizing on opportunities in this field: generating new jobs, increasing incomes, attracting new sources of investments, encouraging entrepreneurship among women (Sikari, 2018). At the same time, the reports of the European Commission (UNWTO and UNEP, 2015) set the following objectives for the implementation of sustainable tourism: economic viability, local prosperity, an increase of jobs quality, social equity, local control, community welfare, cultural wealth, landscape and environmental integrity, biological diversity, resource efficiency. 


\section{CASE STUDY. ANALYSIS OF THE CORRELATION BETWEEN THE NUMBER OF OVERNIGHT STAYS AND THE GROSS DOMESTIC PRODUCT IN CARAS-SEVERIN COUNTY, ROMANIA}

As the general hypothesis of the case study, we start from the idea that there is a direct link between the level of entrepreneurship development and the level of economic growth on the local level, a statement found in the specialized works quoted above.

Thus, to prove this hypothesis, we selected as relevant indicators for the study of the link between entrepreneurship and local economic growth: the total number of overnight stays in the Danube Shore area, respectively Gross Domestic Product in Caraş-Severin county, for 17 years. The data were collected for the years 2001-2017, this being the last year for which there is information on the GDP / county indicator (available in the database of the National Institute of Statistics).

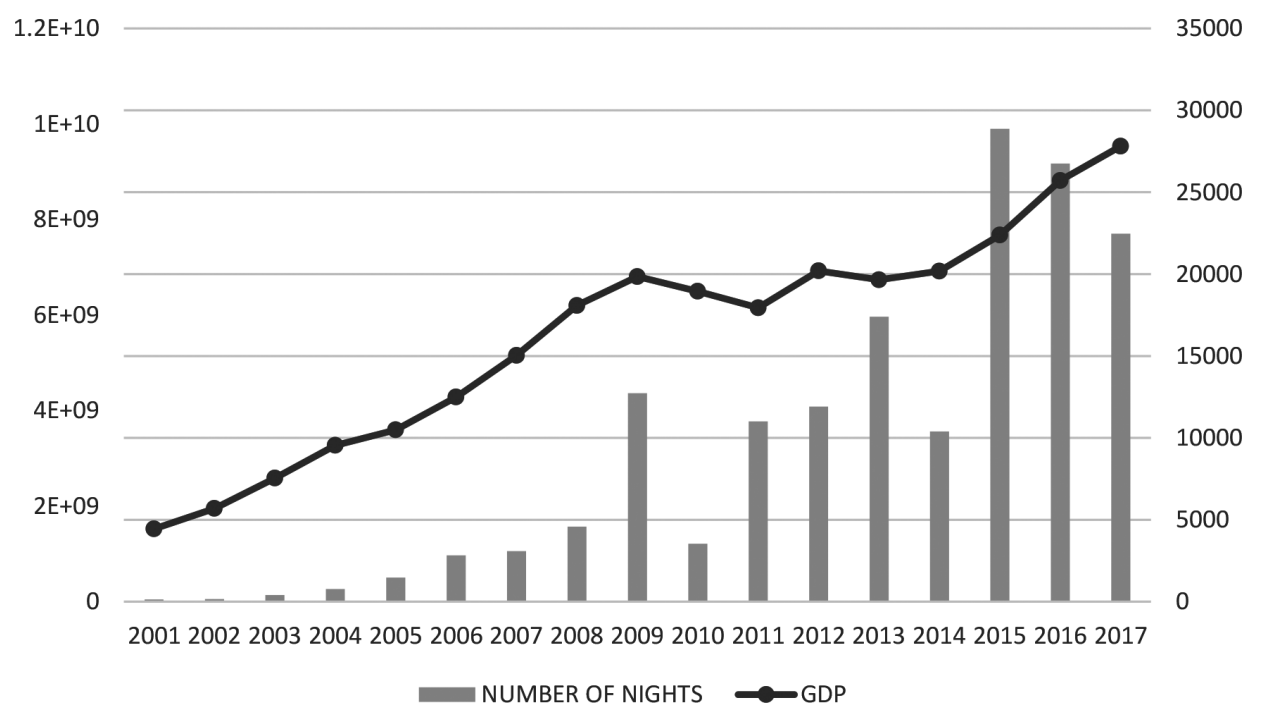

Figure 1. Evolution of GDP and number of overnight stays between 2001 and 2017

Source: data processed by the authors, based on information from www.insse.ro, Tempo online

The information in the graph above was entered into the EViews 11 program and processed, using the following regression equation to analyse the relationship between the two factors:

$$
\mathrm{Y}=\alpha+\beta \times \mathrm{X}+\varepsilon
$$

By replacing the parameters of the above equation with the factors considered relevant for the present study, the calculation relationship becomes:

$$
\mathrm{GDP}=\alpha+\beta \times \mathrm{nN}+\varepsilon
$$

The analysis of the connection between the variables is performed based on the regression equation above, where $\alpha$ and $\beta$ represent the coefficients of the equation ( $\mathrm{C} 1$ and $\mathrm{C} 2), \mathrm{X}$ - the factorial variable (number of nights $-\mathrm{nN}$ ), respectively $\mathrm{Y}-$ the resultant variable (GDP $=$ GDP). The following table shows the values obtained from the data processing in the EViews 11 program. 
Table 2. Regression analysis output

\begin{tabular}{|c|c|c|c|c|}
\hline \multicolumn{5}{|c|}{ Dependent Variable: GDP } \\
\hline \multicolumn{5}{|c|}{ Method: Least Squares (Gauss-Newton / Marquardt steps) } \\
\hline \multicolumn{5}{|c|}{ Date: 11/09/20 Time: 01:15 } \\
\hline \multicolumn{5}{|l|}{ Sample: 20012017} \\
\hline \multicolumn{5}{|c|}{ Included observations: 17} \\
\hline \multicolumn{5}{|l|}{$\mathrm{GDP}=\mathrm{C}(1)+\mathrm{C}(2) * \mathrm{nN}$} \\
\hline & Coefficient & Std. Error & t-Statistic & Prob. \\
\hline $\mathrm{C}(1)$ & $3.63 \mathrm{E}+09$ & $4.45 \mathrm{E}+08$ & 8.168658 & 0.0000 \\
\hline $\mathrm{C}(2)$ & 207444.8 & 33801.30 & 6.137185 & 0.0000 \\
\hline R-squared & 0.715181 & \multicolumn{2}{|l|}{ Mean dependent var } & $5.57 \mathrm{E}+09$ \\
\hline Adjusted R-squared & 0.696193 & \multicolumn{2}{|l|}{ S.D. dependent var } & $2.35 \mathrm{E}+09$ \\
\hline S.E. of regression & $1.29 \mathrm{E}+09$ & \multicolumn{2}{|l|}{ Akaike info criterion } & 44.91023 \\
\hline Sum squared resid & $2.51 \mathrm{E}+19$ & \multicolumn{2}{|l|}{ Schwarz criterion } & 45.00825 \\
\hline Log likelihood & -379.7369 & \multicolumn{2}{|l|}{ Hannan-Quinn criter. } & 44.91997 \\
\hline F-statistic & 37.66505 & \multicolumn{2}{|l|}{ Durbin-Watson stat } & 1.152826 \\
\hline Prob (F-statistic) & 0.000019 & & & \\
\hline
\end{tabular}

The regression equation of the 2 variables, GDP and $\mathrm{nN}$, is:

$$
\mathrm{GDP}=\mathrm{C}(1)+\mathrm{C}(2) \times \mathrm{nN}
$$

where

GDP $=$ dependent variable (resultant)

$\mathrm{nN}$ - factorial variable (independent)

$\mathrm{C}(1)$ and $\mathrm{C}(2)$ - the coefficients of the regression equation

Substituting the calculated values, the regression equation becomes:

$$
\mathrm{GDP}=3,63+207.444,8 \times \mathrm{nN}
$$

The coefficient $\mathrm{C}(1)$ has a standard error of 4.45 , this being the free term of the equation. It represents the value that the resultant variable takes if the factor number of nights has the value zero. The regression coefficient $\mathrm{C}(2)$ has a standard error of 33801.3. The positive sign of this coefficient shows the existence of a direct link between the two variables, therefore, as the number of overnight stays increases, so does the GDP.

The intensity of the connection of the 2 variables can be studied in this case as well, using the R-squared correlation coefficient. In the situation presented in the table above, we find a strong and direct link between the two indicators analysed, given that the calculated value of the correlation coefficient (0.715) tends to the maximum limit of the interval (1). We can therefore see that the variable number of overnight stays positively influences the evolution of GDP, in the proportion of $71.5 \%$.

At the same time, the regression coefficient $\mathrm{C}(2)$ indicates a direct link between the factorial variable and the resultant one, this being also very strong (the variation with one unit of the factorial variable determines the variation of the resultant one with an above-the-unit value). 
The results obtained in the case of the above unifactorial model can also be analysed through statistical tests. In this sense, we proceeded to determine the values of the Student, Fisher and Durbin-Watson tests.

As regards the Student test, its value (t-Statistic), corresponding to $C(1)$ is 8.16 , and for $C(2)$ it is 6.13. From the table related to the Student distribution, we notice that $t_{\text {critic }}$ (determined according to $\mathrm{v}=16$ degrees of freedom and the probability $0.05 / 2=0.025$ ) is equal to 2.120 . This value, compared to $\mathrm{tc}_{1}$ and $\mathrm{tc}_{2}$, respectively, indicates that the null hypothesis is rejected, and we can state with a $95 \%$ probability that the model is statistically correct, and there is a direct and strong link between the two variables.

According to the data in the table above, the value of the Durbin-Watson test (d) is equal to 1.15. From the statistical tables related to this distribution we can identify a lower table value $\mathrm{dL}=$ 1.13, respectively an upper table value $\mathrm{dU}=1.38$, taking into account a significance level of the test $=0.05$, as well as the number of observations (17), being used by this given a single factorial variable, $\mathrm{k}$. The comparisons between the tabular values and the calculated value of the test indicate, however, the need to resume the calculations on an extended sample of data, the result being inconclusive, a fact indicated by the relation $\mathrm{dL}<\mathrm{d}<\mathrm{du}(1.13<1.15<1.38)$.

The calculated value of the Fisher test (F-statistic) is 37.66. From the Fisher-Snedecor distribution table, we notice that the critical value $\mathrm{Ft}=4.49$, taking into account the significance level 0.05 and the number of degrees of freedom. Following the comparison of the two values, we find that $\mathrm{Fc}>\mathrm{Ft}$, as a result, the null hypothesis is rejected with a probability of $0.95 \%$, indicating a significant level of influence of the number of overnight stays on the GDP indicator.

\section{THE DANUBE SHORE (CLISURA DUNĂRII) - THE "HERALD" OF TOURISM IN BANAT, ROMANIA}

After flowing through six countries (Germany, Austria, Slovakia, Hungary, Croatia, Serbia) and crossing four capitals (Vienna, Bratislava, Budapest, and Belgrade), the river that springs from the Black Forest Mountains continues its adventure, entering the Romanian territory at Baziaș, a locality situated in Caraş-Severin county, and flowing for $60 \mathrm{~km}$ in the county, at the border with the Republic of Serbia. The Danube Shore (in Romanian Clisura Dunării, in Serbian Banatska Klisura, in Cyrillic characters Банатска Клисура) comprises the longest gorge in Europe, the Danube Shore (135km), being the "herald" of tourism in Banat (Popovici, 2016), an unparalleled teller of the history of these places, from Baziaș to the Iron Gates (in Romanian Porţile de Fier, in Serbian Gvozdena vrata, in Cyrillic characters Гвоздена врата).

The most famous localities in the Danube Shore are the towns of Moldova Nouă (Caraş-Severin County) and Orşova (Mehedinți County). The area also includes the communes of Socol, Pojejena, Coronini, Gârnic, Sichevița, Berzasca (Caraș-Severin County), Svinița, Dubova, Eșelnița, Ilovița and Breznița-Ocol (Mehedinți County).

The Danube Shore or the Danube Gorge (Clisura Dunării), as it is called specially by the locals, a spectacular area not only from a historical or geographical point of view, is also a multicultural territory, being inhabited by Romanians, along with many Serbs (some localities having even the majority Serb population), an important German or Czech communities. Although wars, different political regimes, and many other turmoils passed over these localities, the people of 
the area, especially those from rural localities, did not forget their faith, traditions, customs, and, especially, their language, unaltered by neologisms. Extremely rich in historical and cultural testimonies, the Danube Shore is of great interest in terms of biodiversity, on its territory being important to nature reserves, currently included in the Iron Gates Natural Park.

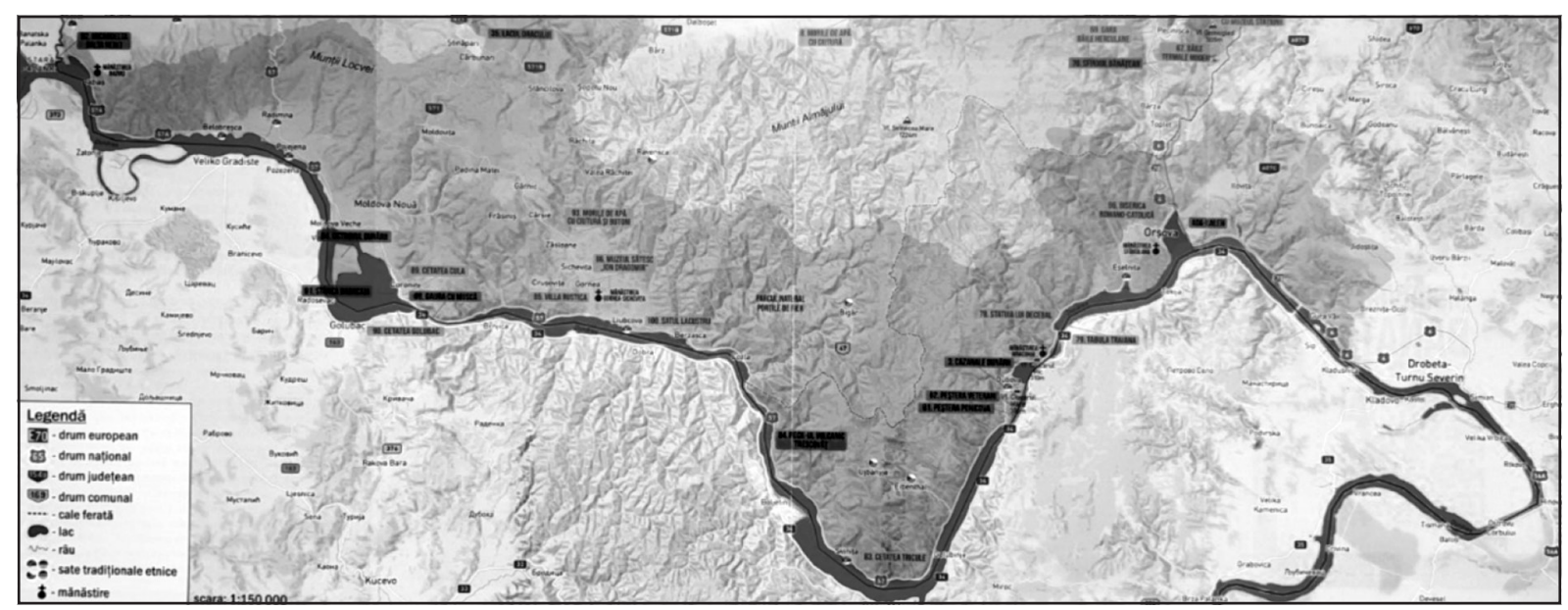

Figure 2. Map of the Danube Shore

Source: aplicatie.banatul-montan.ro

Undoubtedly, the Danube Shore is a masterpiece of God, it is a place shrouded in mystery and a perfect spectacle of nature. Nevertheless, is the Danube Shore a successful touristic area? Or at least can it become one?

\section{STUDY REGARDING THE TOURISTIC POTENTIAL IN THE DANUBE SHORE AREA (CLISURA DUNĂRII)}

\subsection{Research methodology}

In order to study the perception of the population in Romania and, in particular, of Banat inhabitants, about the touristic potential in the Danube Shore, as well as the possibilities of capitalizing on this potential, we used a questionnaire-based survey as the research method.

The survey is, according to the literature, one of the most complex methods of psycho-sociological investigation. It involves the collection of certain pieces of information, usually with the help of interviews and/or questionnaires (Curelaru, 2003, p. 45), from a sample extracted from the investigated population, a larger population, with the purpose of processing and generalizing the results.

The sociology dictionary defines the questionnaire as an ,investigative tool, consisting of a set of written questions and possibly graphic images, logically and psychologically ordered which, when administered by survey operators or through self-administration, determine from the respondents' answers that are recorded in writing (S. Chelcea, The questionnaire in the sociological investigation, 1975). In sociological research, the questionnaire is used to collect both objective data (age, sex, level of education, income, etc.) and subjective data (opinions, attitudes, aspirations, needs, etc.)." (Zamfir \& Vlăsceanu, 1998, p. 95).

Based on these considerations, the main tool of this research was an online questionnaire, applied in a written form using Google Forms. This method of application was imposed, in par- 
ticular, by the peculiarities of the current context, generated by the presence of the SarsCov2 virus, a situation that required the limitation of physical contacts, the questionnaire is administered in October and November 2020.

The main objective of the research was the analysis of the respondents' perception regarding the extent to which the Danube Shore can become a successful touristic destination.

The secondary objectives were the following:

OS1. identifying the level of familiarity of the respondents with the Danube Shore area;

OS2. identifying the extent to which subjects could choose the Danube Shore as a touristic destination and the main ways to spend their free time;

OS3. identifying the most important factors that determined respondents to visit the Danube Shore;

OS4. identifying the most appreciated tourists' objectives in the area;

OS5. identifying the level at which the Danube Shore is considered an accessible destination in terms of transport;

OS6. identifying the general level of attractiveness of the Danube Shore;

OS7. identifying the respondents' perception regarding the localities in the Danube Shore that would have the greatest chances to become successful touristic destinations.

In order to reach these objectives, a questionnaire consisting of 27 questions was designed and distributed online, consisting of 6 identification questions and 21 content questions. Of these, this paper presents the results obtained for 13 content questions, the others to be developed in a subsequent study, which intends to deepen the analysis of the investigated issues.

The identification questions referred to the gender of the respondents, their age, main occupation, level of education, net income per family member, area of residence. The structure of the questionnaire was complex, comprising both closed questions, with single or multiple answer options, and questions based on measurement scales, the respondents awarding a 1-to-5 score to the proposed criteria, according to Likert's scale.

\subsection{Interpretation of data obtained and research conclusions}

The sample consisted of 333 people, $67.3 \%$ female, and $32.7 \%$ male.

Regarding the distribution of subjects by age groups, most respondents fell into the category of 25-34 years (27\%), being closely followed by those under 25 years $(25.5 \%)$, as well as those with age between 35 and 44 years $(24.9 \%)$, the lowest number of answers coming from people over $65(1.2 \%)$. The structure of the sample, according to the distribution of respondents by gender and age groups, is shown in the graphs 3 and 4.

Out of the total respondents, more than two-thirds are employed, a little more than a quarter are school pupils/students and college students, very few are unemployed, housewives or pensioners (less than 5\%).

$39.3 \%$ of the respondents are master's graduates, $36.9 \%$ have a bachelor's degree, $18.6 \%$ are high school graduates and $4.8 \%$ declare to have a Ph.D. 
Most of the subjects (32.1\%) stated that their net monthly income per family member is between 1500 - 2500 lei (approximately 300 - 500 euros) and only $15.6 \%$ of the respondents have a net monthly income below 1500 lei (less than 300 euros). It should be mentioned that $24.3 \%$ earn 2500 - 3500 lei (approximately 500 - 700 euros), 11.7\% have incomes between 3500 - 4500 lei (approximately 700 - 900 euros per family member), and 16.2\% earn net monthly incomes even higher than 4500 lei (approximately over 900 euros per family member).

As for the area of residence, over three-quarters of the subjects come from urban areas and only $24.6 \%$ of the interviewed persons live in rural areas.

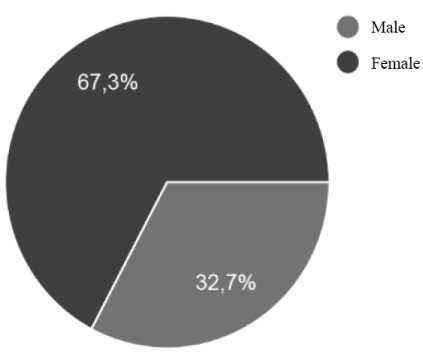

Figure 3. Sample structure by gender

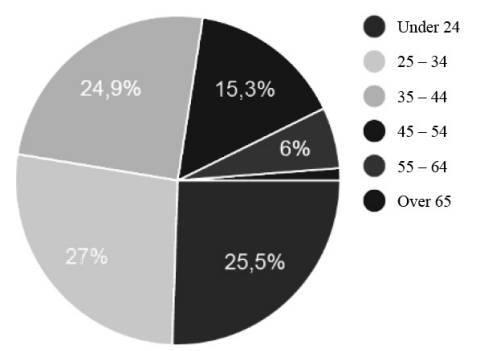

Figure 4. Sample structure by age groups

Source: elaborated by the authors

When it comes to the content questions, following the centralization of the results, we reached the following conclusions regarding the proposed objectives:

1. Regarding the level of familiarity with the Danube Shore, $61.8 \%$ of the subjects stated that they are familiar or even very familiar with this touristic area, and only $14.4 \%$ state that they are less or not at all familiar with the Danube Shore. The verification of the representativeness of the answers provided by the respondents indicates a value of $31.94 \%$ of the variation coefficient, therefore we find a fairly high level of homogeneity of the analyzed sample.

2. The vast majority of respondents (85\%) say they would choose the Danube Shore as a leisure destination, $11.4 \%$ say they are neutral, while those who say they would not spend their leisure time in this area are extremely few (only 3.6\%). In this situation also we identify a significant level of representativeness, proven by the level of the calculated coefficient of variation: about $19.23 \%$.

3. For most people who constituted the researched sample, the 3 main factors that would cause them to visit the Danube Shore are, in order: natural attractions, leisure opportunities, and anthropogenic attractions. On the other hand, other factors such as the cost of travel or proximity to the residence are less important for respondents.

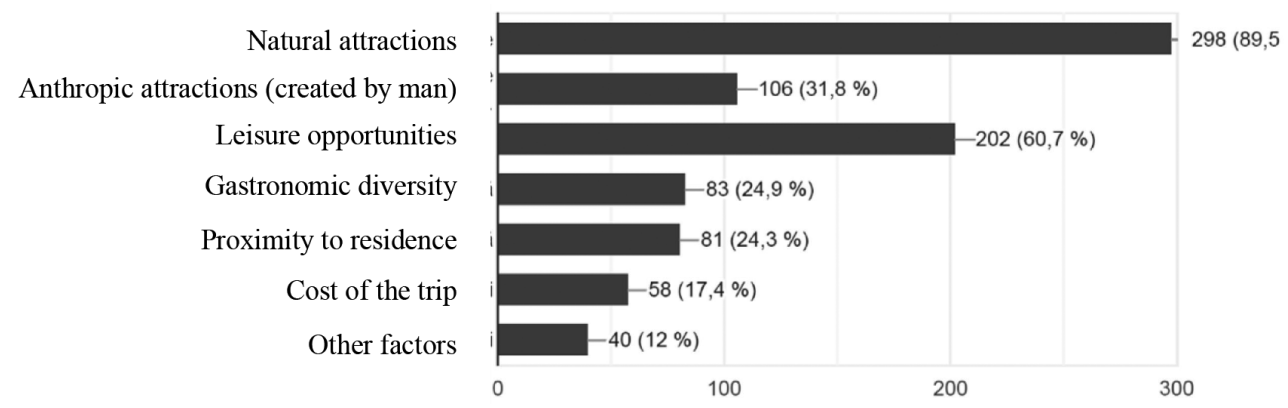

Figure 5. Factors that determined the respondents to visit the Danube Shore

Source: elaborated by the authors 
4. Among the natural or anthropic touristic sights, the most appreciated by the respondents are, in order, the following: Decebal's carved face, Baba Caia Rock and the Ostrov Island, as well as Saint Ann / Sfânta Ana Monastery of Orșova. A fairly large number of ,votes” were awarded to other tourist attractions, such as the Nera Microdelta, the Macronia Monastery and the Lacustrine Village.

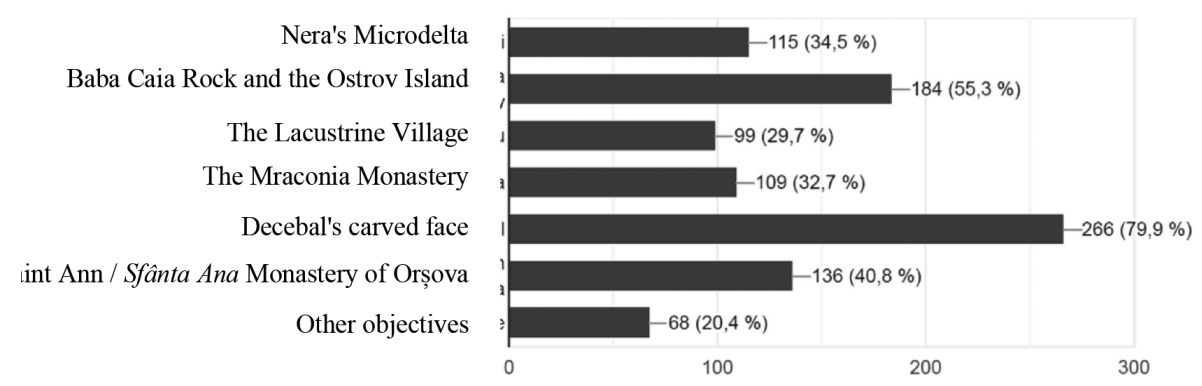

Figure 6. Touristic sights that would determine the respondents to visit the Danube Shore

Source: elaborated by the authors

5. As for the means of transport by which they travelled to the Danube Shore on their last visit, the overwhelming majority (86.8\%) state they went by car, being extremely few, on the other hand, those who claim to have travelled by train or minibus (they totalled $0.6 \%$ of the respondents), by bicycle/motorcycle (1.2\%), by ship/boat (1.5\%).

6. Most respondents (63.9\%) consider the Danube Shore accessible in terms of transport, but, on the other hand, $11.1 \%$ consider the area very inaccessible and almost a quarter $(24.9 \%)$ say they are neutral in this regard. Correlating this question with the previous one, we can easily realize that, not being able to travel by car, the Danube Shore becomes, in fact, less accessible for people who would like to reach this area by other transport means. There is also high representativeness of the answers, the calculated level of the coefficient of variation being $28.48 \%$.

7. The Danube Shore is considered by most respondents to be an appropriate destination, primarily for families with children, groups and youth. It should also be mentioned that many people consider the Danube Shore a good destination for organizing events with family or friends, for couples, for seniors, or even for team building/workshops.

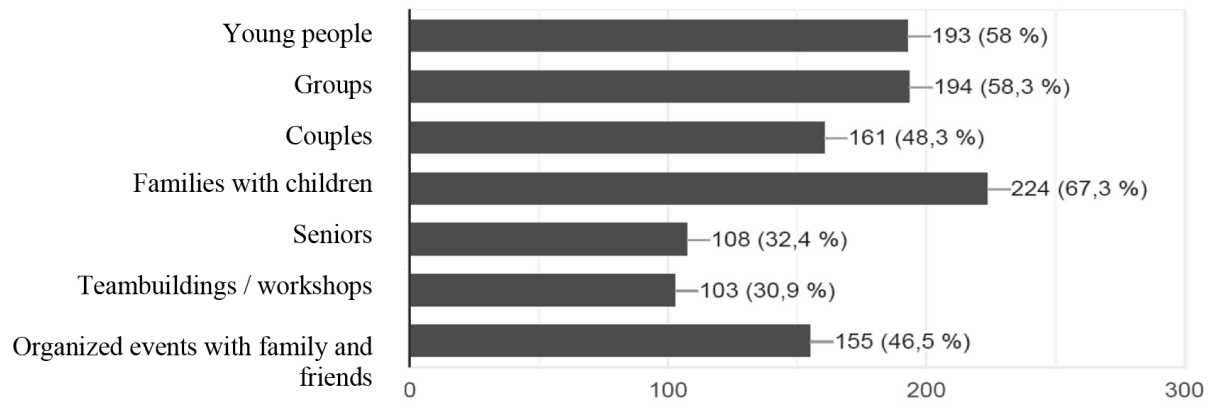

Figure 7. Target public category for the Danube Shore

Source: elaborated by the authors

8. As regards how they would like to spend their time in the Danube Shore, most of the respondents to the questionnaire said they would like to get to this area for hiking, rest, and recreation, but, especially for boating. On the other hand, there are quite a few who say that they would like to come to the Danube Shore for cycling, pilgrimages and religious meetings, or for other activities. 


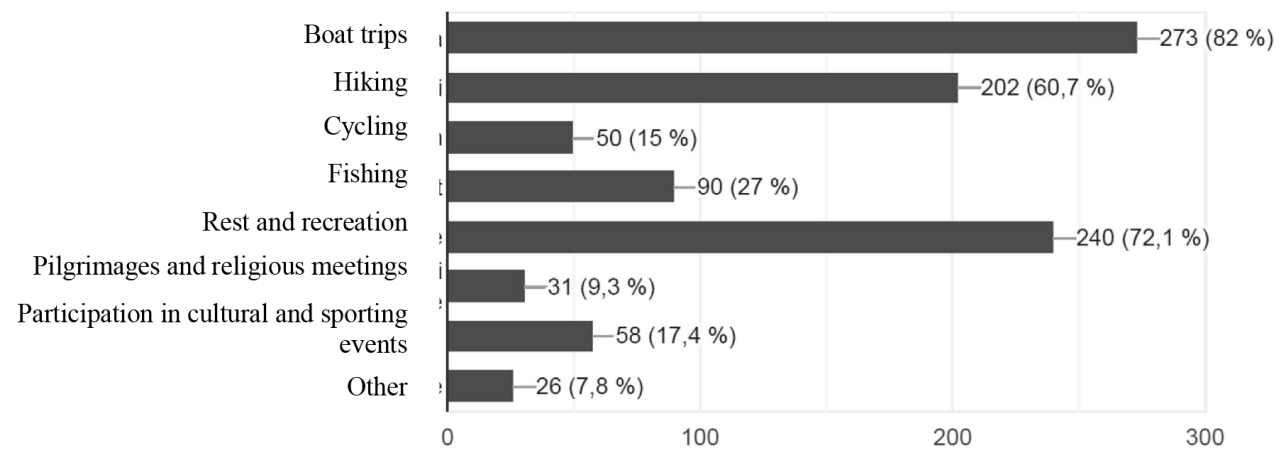

Figure 8. How the respondents would like to spend their time in the Danube Shore

Source: elaborated by the authors

9. When asked how they appreciate the level of attractiveness of the Danube Shore, the vast majority of respondents $(85.9 \%)$ consider this area to be attractive and even very attractive, $12.3 \%$ say they are neutral and only $1.8 \%$ consider the Danube Shore unattractive. These results practically reflect the very high interest of people for the analyzed area, a fact confirmed also from a statistical point of view, by determining the variation indicator, which registers a high level of homogeneity (17.81\%).

10. Most of those who visited the Danube Shore say they would recommend this area to other people in full confidence, first of all for the beauty of the landscape, but also the touristic sights. The leisure opportunities, accommodation conditions, gastronomic diversity are other criteria according to which the respondents would recommend the Danube Shore, mostly the positive recommendations generally referring to the aspects related to the rates or the quality-price ratio.

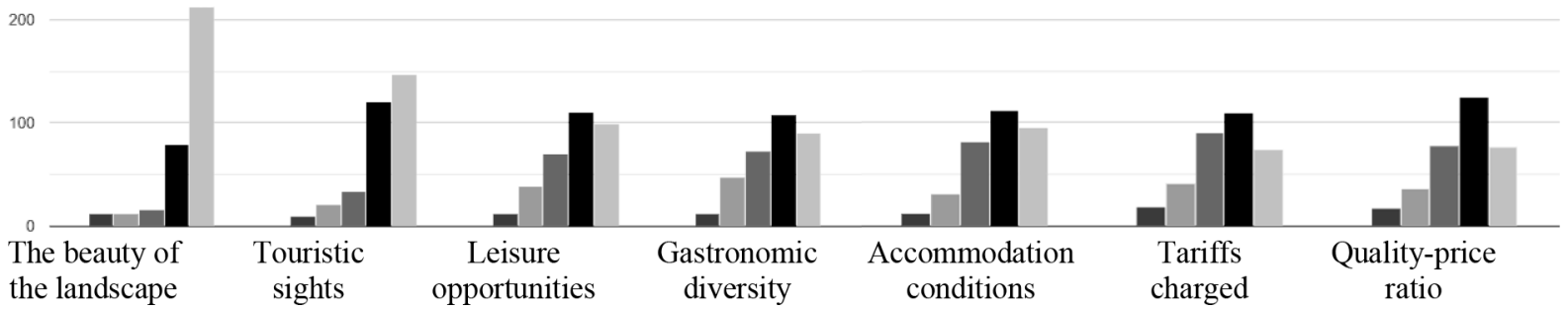

to a very low extent

indifferent

to a low extent

to a high extent to a very high extent

Figure 9. Criteria for which respondents recommend the Danube Shore

Source: elaborated by the authors

11. Almost three-quarters of those who answered the questionnaire (73\%) say they would certainly return to the Danube Shore, $18 \%$ of subjects say that for them the possibility of returning to this area is quite high and only $1.5 \%$ say they would rather not return. It should be noted that there was absolutely no one to declare he or she would not return to the Danube Shore.

12. It is remarkable that $93.1 \%$ of the subjects consider that, to a high extent and/or even to a very high extent, the Danube Shore area can become a successful touristic destination.

13. The localities with the highest chances to become appreciated touristic destinations are the following, in the respondents' perception: the town of Orșova, followed by the communes of Berzasca, Dubova, and Coronini (the last being also known as Pescari). It should be mentioned that the town of Moldova Nouă, even if it was not ranked among the first four 
nominations by most of the surveyed subjects, is still in the first part of the top of Danube Shore localities credited with the opportunity to become successful touristic destinations. Also, the commune of Eșelnița is seen by many of the respondents as a locality with quite high possibilities to become a successful touristic destination.

On the other hand, localities such as Sichevița, Svinița, Gârnic, Pojejena, and, especially, Socol are listed with little chance of becoming attractive from the tourists' point of view.

It should be noted that there are some very skeptical respondents (4.2\%), for whom none of the above localities has a chance to become a successful tourist destination.

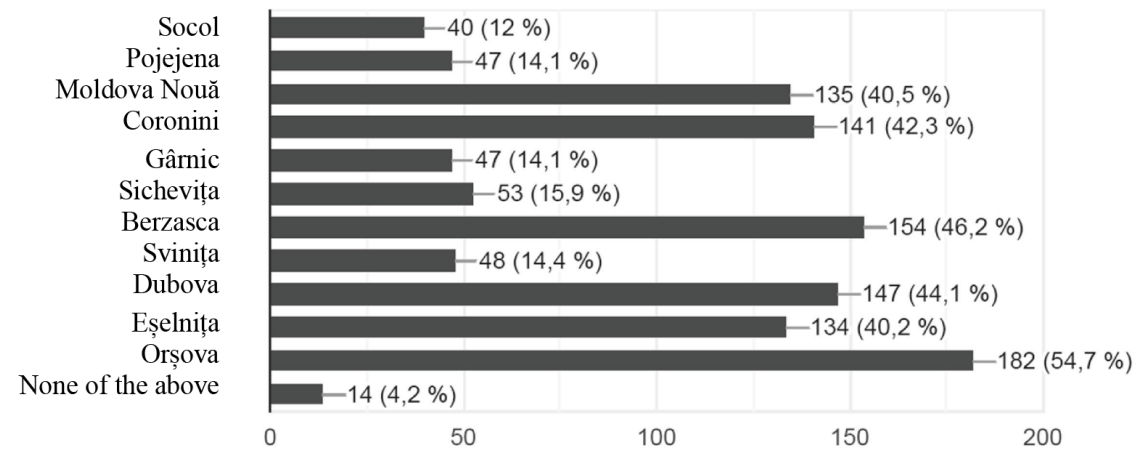

Figure 10. Localities considered having the potential

to become successful touristic destinations

Source: elaborated by the authors

\subsection{Verification of results}

Each objective presented at the beginning of the study corresponds to at least one of the criteria found in the table below, the degree of homogeneity is determined for the criteria where the answers involved the use of the Likert scale, by the following statistical indicators: weighted arithmetic mean, dispersion, square deviation, and the coefficient of variation, respectively.

In the case of all the questions that involved the use of the Likert scale, we can remark a high level of homogeneity of answers, as a result, the sample on which the research was conducted is a representative one. However, the topic addressed in this chapter is very broad and offers many opportunities to be continued and enhanced, and can be extended in a study involving a larger sample, including subjects from most Romanian counties and, why not, even from other countries.

Table 3. Statistical verification of results

\begin{tabular}{|c|c|c|c|c|c|}
\hline Objective & $\begin{array}{l}\text { Correspond- } \\
\text { ing question }\end{array}$ & $\begin{array}{c}\text { Weighted } \\
\text { arithmetic } \\
\text { mean } \\
\end{array}$ & Dispersion & $\begin{array}{c}\text { Average } \\
\text { square devi- } \\
\text { ation } \\
\end{array}$ & $\begin{array}{l}\text { Variation } \\
\text { coefficient }\end{array}$ \\
\hline $\begin{array}{l}\text { OS1. identifying the level of familiarity } \\
\text { of the respondents with the Danube Shore } \\
\text { area; }\end{array}$ & Q1 & 3.7928 & 1.4675 & 1.2114 & $31.94 \%$ \\
\hline $\begin{array}{l}\text { OS2. identifying the extent to which sub- } \\
\text { jects could choose the Danube Shore as a } \\
\text { touristic destination and the main ways to } \\
\text { spend their free time; }\end{array}$ & $\begin{array}{l}\text { Q2 } \\
\text { Q7 } \\
\text { Q8 }\end{array}$ & $\begin{array}{r}4.4294 \\
* * * \\
* * *\end{array}$ & $\begin{array}{r}0.7255 \\
* * * \\
* * *\end{array}$ & $\begin{array}{r}0.8517 \\
* * * \\
* * *\end{array}$ & $\begin{array}{r}19.23 \% \\
* * * \\
* * *\end{array}$ \\
\hline
\end{tabular}




\begin{tabular}{|c|c|c|c|c|c|}
\hline $\begin{array}{l}\text { OS3. identifying the most important fac- } \\
\text { tors that determined respondents to visit } \\
\text { the Danube Shore; }\end{array}$ & Q3 & $* * *$ & $* * *$ & $* * *$ & $* * *$ \\
\hline $\begin{array}{l}\text { OS4. identifying the most appreciated } \\
\text { tourists' objectives in the area; }\end{array}$ & Q4 & $* * *$ & $* * *$ & $* * *$ & $* * *$ \\
\hline $\begin{array}{l}\text { OS5. identifying the level at which the } \\
\text { Danube Shore is considered an accessible } \\
\text { destination in terms of transport; }\end{array}$ & $\begin{array}{l}\text { Q5 } \\
\text { Q6 }\end{array}$ & $\begin{array}{r}* * * \\
3.8679\end{array}$ & $\begin{array}{r}* * * \\
1.2138\end{array}$ & $\begin{array}{r}* * * \\
1.1017\end{array}$ & $\begin{array}{r}* * * \\
28,48 \%\end{array}$ \\
\hline $\begin{array}{l}\text { OS6. identifying the general level of at- } \\
\text { tractiveness of the Danube Shore; }\end{array}$ & Q9 & $\begin{array}{r}4.3544 \\
* * * \\
\end{array}$ & $\begin{array}{r}0.6011 \\
* * * \\
\end{array}$ & $\begin{array}{r}0.7753 \\
* * *\end{array}$ & $\begin{array}{r}17.81 \% \\
* * * \\
\end{array}$ \\
\hline $\begin{array}{l}\text { OS7. identifying the respondents' percep- } \\
\text { tion regarding the localities in the Danube } \\
\text { Shore that would have the greatest chances } \\
\text { to become successful touristic destinations }\end{array}$ & $\begin{array}{l}\text { Q12 } \\
\text { Q13 }\end{array}$ & $\begin{array}{r}4.6036 \\
* * *\end{array}$ & $\begin{array}{r}0.4194 \\
* * *\end{array}$ & $\begin{array}{r}0.6476^{*} \\
* * *\end{array}$ & $\begin{array}{r}14.07 \% \\
* * *\end{array}$ \\
\hline
\end{tabular}

Source: calculations performed by the authors, based on the data collected from the answers to the questionnaire

\section{CONCLUSION}

Tourism is a global driving force that engages different types of industries, both vertically and horizontally. Practicing sustainable tourism, which respects the particularities of the various areas and is friendly to the environment, is the imperative requirement of our days. Tourism is a source of income for those areas that attract grace to natural scenery, anthropogenic sights, leisure time offers, or gastronomic diversity.

The Danube Shore or Gorge, in Romanian Clisura Dunării, as it is known by the locals, can be one of the areas of this type. From the statistical data presented, correlated, and interpreted herein, from the descriptions that appear in the tourism literature, as well as from the results of the questionnaire-based survey, it is crystal clear that the Danube Shore is an area with great touristic potential.

These past years exhibit the development of the area, starting from the modernization of the road along the Gorge, the increase of the number of accommodation units for tourists, the diversification of the leisure offers boat rides, bicycle routes, fishing, hiking, etc. At the same time, it should be mentioned that the quality of the services offered has increased: 4 and 5-star ("daisies") pensions, with relaxation areas, swimming pools among the most spectacular in Romania, with increasingly diversified and surprising menus served.

According to the results of the survey, the Danube Shore can attract through the beauty of the natural landscape and the anthropogenic sights, being, at the same time, an area recommended for relaxation and recreation. The vast majority of subjects stated that the general level of attractiveness of the area is very high, being a suitable destination for leisure for young people, as well as for couples, families with children and seniors, the respondents saying they intend to return to the area, and also to recommend it to acquaintances.

The increase in the number of tourists in this area means that its potential is not fully exploited, but there is hope in this regard. Also, the fact that the number of overnight stays in the accommodation areas along the Danube Shore, although increasing, is still quite low, proves, once again, that the area is not currently exploited to its true potential. 
The town of Orșova, the village of Dubova with the Danube Boilers, the Lacustrine Village at Berzasca, as well as the village of Corinini are considered by the survey subjects to be localities in the Danube Shore that can become successful destinations. But for this to become reality, the collaboration between the private sector and the authorities must be as close as possible.

Therefore, the efforts for the economic relaunch of Caraş-Severin County and, in this case, of the Danube Shore, could start from the very tourism industry, given the multiplier effect on the zonal economy by engaging local resources, by creating new places, and by attracting surplus labour from neighbouring localities, especially in rural areas, as well as by attracting investors who understand that the area offers huge opportunities to implement profitable business ideas.

It becomes clear that both in terms of infrastructure and touristic facilities, serious investment is needed for the Danube Shore area to turn it into a truly successful touristic destination and, in this context, adequate support should come from the public administration, which may finally lead, at the end of the day, to the intended improvements so much needed for the development of entrepreneurial activities in the analyzed area.

\section{REFERENCES}

Akrivos C., Panayiotis R. \& Theodoroyiani M. (2014). Tourism Entrepreneurship and the Adoption of Sustainable Resources. The Case of Evritania Prefecture. Procedia - Social and Behavioral Sciences, 148, 378 - 382.

Ashley C., De Brine P., Lehr A. \& Wilde H. (2007). The role of the tourism sector in expanding economic opportunity. Corporate social responsibility initiative report, no 23, MA: Kennedy, School of Government, Harvard University.

Bardolet, E. \& Sheldon, P. J. (2008). Tourism in Archipelagos: Hawai'i and the Balearics. Annals of Tourism Research, no.35, 900-923.

Bednarczyk M. \& Gancarczyk J. (2013). Entrepreneurship in tourism and sport. A Quarterly Journal of Nowy Sacz School of Business, National Louis University, vol. 9, issue 1

Biswas C. \& Mamun-Or-Rashid M. (2018). The Role of Tourism Entrepreneurship Businesses in the Economic Development: An Overview. International Journal of Business and Tehnopreneurship Volume 8, No 2, 167-176.

Brookes M. \& Altinay L. (2015). Entrepreneurship in hospitality and tourism. A global perspective. Oxford: Goodfellow Publishers Limited.

Butkouskaya V., Romagosa F. \& Noguera M. (2020). Obstacles to Sustainable Entrepreneurship amongst Tourism Students: A Gender Comparison. Sustainability 2020 (12), 1812. doi:10.3390/su12051812

Çağlayan A. E., Şak N. \& Karymshakov K., (2012). Relationship between tourism and economic growth: a panel granger causality approach. Asian Economic and Financial Review 2(5), 518-529. http://aessweb.com/journal-detail.php?id=5002

Carvalho L.M.C. \& Sardinha B.B., (n.d.) Entrepreneurial Environmental Conditions for Promoting Sustainable Tourism, http://www.smia.info/files/ehad2kof.f1_fr-1365.pdf

Ciochină, I., Iordache, C. M. \& Sîrbu, A., (2016). Entrepreneurship in the tourism and hospitality industry. Management Strategies Journal, 31(1), 264-275. http://www.strategiimanageriale.ro/papers/160136.pdf

Curelaru, M. (2003). Manual de psihologie social / Manual of social psychology. coord. Adrian Neculau, Iași: Polirom Publishing House. 
Dees, J. G. (2002). Strategic tools for social entrepreneurs. Enhancing the performance of your enterprising nonprofit, nonprofit law, finance \& management series. Indianapolis, IN: Wiley.

Forouzandeh, M., Safahani N. \& Fakhrabadi, M. K. (2015). Factors affecting entrepreneurship: tourism development and sustainable tourism industry. International Journal Of Modern Management \& Foresight, Vol.2. Issue 2, 65-76.

Gică, O. A., Nemeș C. - L. \& Moisescu, O. - I., (2014). Determinants of tourism entrepreneurship: the case of Straja resort. Studia UBB Negotia, LVIX, 4, 77 - 89.

Gherghina L. (2017). The touristic potential of Caraş-Severin County. Annals of the „Constantin Brâncuşi" University of Târgu Jiu, Economy Series, Issue 5, pp. 77 - 87

Gherghina L. (2018). Touristic activity in hotels. Annals of "Eftimie Murgu" University Resita. Fascicle II. Economic Studies, vol. XXV, pp. $69-81$

Jaafar M., Abdul - Aziz A. R., Maideen S. A. \& Mohd S. Z. (2011). Entrepreneurship in the tourism industry: Issues in developing countries. International Journal of Hospitality Management, 30, pp. 827-835

Li, L. (2008). A review of entrepreneurship research published in the hospitality and tourism management journals. Tourism Management, 29(5), 1013-1022.

Lordkipanidze M., Brezet H. \& Backman M. (2005). The entrepreneurship factor in sustainable tourism development. Journal of Cleaner Production, 13, pp. 787-798

Manciu V. (2019). An analysis regarding the development potential of the Romanian business environment and the role of the Competition Council. Annals of "Eftimie Murgu" University Resita. Fascicle II. Economic Studies, vol. XXVI, pp. 143 - 149

Maticiuc M. \& Petrache A. C. (2016), Industrial Parks and Business Incubators as Clustering Incipient Forms. 7th International Multidisciplinary Symposium „, Sustainable development through quality and innovation in engineering and research", Conference Proceedings, Universitaria SIMPRO, University of Petroşani, Romania

Marwa M., Mohamed A.S. \& Nancy F. (2019). The Role of Governmental Authorities in Supporting Entrepreneurship in Tourism. International Journal of Heritage, Tourism and Hospitality, Vol. (13), No. (2), September, pp.107-123, https://ijhth.journals.ekb.eg/article 92756 d0f0d540d6cladb8c5163d2810db9b25.pdf

Nongsiej P. \& Shimray S. (2017). The role of entrepreneurship in tourism industry: An Overview. Conference paper, Seminar on Entrepreneurial Opportunities for Educated Youth in Global Business

Oliveira E. (2014). The tourism potential of Northern Portugal and its relevance for a regional branding strategy. Advances in Hospitality and Tourism Research, 2(2), 54-78. http:// www.ahtrjournal.org/admin/dosyalar/8/AHTR2(2)-5.pdf

Pădurean, M.A., Nica, A.M. \& Nistoreanu, P. (2014). Entrepreneurship in tourism and financing through the Regional Operational Programme. Amfiteatru Economic, 17(38), pp. 183-197

Popovici G. (2016). Banatul montan: ghid turistic / The Mountainous Banat. A Tourists' Guide, Reșiţa: TIM Publishing House.

Sheikh R. (2015). Challenges and possibilities in small tourism businesses. Thesis, University of Applied Sciences

Sikari, S. (2018). Women Entrepreneurship In Tourism Industry; A Study On Women Entrepreneurial Opportunities In Tourism Industry Of West Bengal. IOSR Journal of Business and Management, pp. 60-67

Sima E., Bordânc F. \& Sima C. (2015). Entrepreneurship role in promoting rural tourism. Agricultural Economics and rural development. Institute of Agricultural Economics, Romanian Academy, Bucharest, 12, no 1, pp. 71-80 
Štetić, S., \& Trišić, I. (2018). The role and importance of ecosystems in creating tourism activities. Hotel and Tourism Management, 6(2), 35-46. doi:10.5937/menhottur1802043S

Štetić S. \& Trišić I. (2019). The importance of ecotourism for the development of tourism destination - a case study of the special nature reserve "Meadows of Great Bustard", Vojvodina, 4th International Thematic Monograph, Modern Management Tools and Economy of Tourism Sector in Present Era, Belgrade

Volintiru C. \& Ștefan G. (2018). Aspen Institute Romania, Economic development and opportunities in Romania: local business environment index, White Paper, https:/aspeninstitute.ro/ wp-content/uploads/2018/10/WHITE-PAPER_Economic-Opportunities-Program_2018.pdf

Zamfir, C. \& Vlăsceanu, L. (coord.). (1998). Dicționar de sociologie / Dictionary of Sociology, Bucharest: Babel Publishing House.

Zimmerman, M. A., \& Chu, H. M. (2013). Motivation, success, and problems of entrepreneurs in Venezuela. Journal of Management Policy and Practice, 14(2), 76-90

World Tourism Organization, European Commission. (2013) Sustainable Tourism for Development Guidebook. Enhancing capacities for sustainable tourism for development in developing countries

https://www.unwto.org/statistic-data-economic-contribution-of-tourism-and-beyond OECD, 2020, Tourism trends and policies. Key findings

https://ec.europa.eu/eurostat/cache/RCI/\#?vis=nuts2.tourism\&lang=en

www.insse.ro, Tempo online database 